\title{
Eldgos og heilsa
}

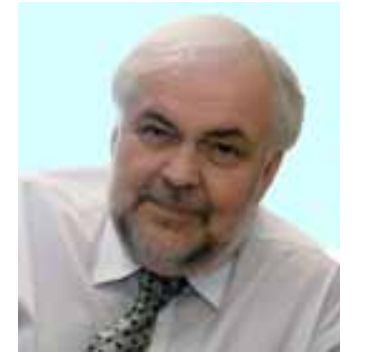

Pórarinn Gíslason

thorarig@landspitali.is

Höfundur er lungnalæknir á Landspítala Fossvogi.

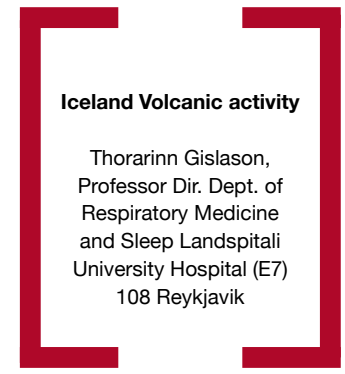

Enda pótt í Vestmannaeyjagosinu í janúar 1973 hafi orðið röskun á högum púsunda Íslendinga hefur fréttum af nýju eldgosi yfirleitt fylgt eftirvænting og jafnvel tilhlökkun meðal flestra núlifandi Îslendinga, væntingar um að framundan sé enn eitt stórkostlegt sjónarspil náttúrunnar. „Ertu búin(n) að fara og sjá gosið?“ Flott, fylgir pví að búa á Íslandi. Gosið á Fimmvörðuhálsi byrjaði á pann veg, en pegar Eyjafjallajökull opnaði gíga sína blasti við ný mynd með lömun á flugi og miklu öskufalli sem raskað hefur lífi fjölda manns. Pessum náttúruhamförum hefur fylgt óöryggi og vanlíðan, jafnframt pví sem áleitnar spurningar hafa vaknað um heilsufarslega skaðsemi eldgossins, bæði í bráð og lengd.

Eldgosum fylgja bæði skaðlegar lofttegundir og fíngerð aska sem hvortveggja getur haft áhrif á heilsufar, allt eftir samsetningu og magni eiturefna. Enda pótt nær tíundi hluti mannkyns búi í innan við $100 \mathrm{~km}$ fjarlægð frá virku eldfjalli er lítið vitað um áhrif eldgosa á heilsufar manna og dýra. Nýjustu yfirlitsgreinar ${ }^{1-3}$ sem eru um fimm ára gamlar hafa vakið athygli á pessum pekkingarskorti og um leið bent á að heilsufarsleg áhrif eldgosa séu mjög mismunandi eftir efnainnihaldi (til dæmis magn brennisteinssýru) og eðli gosösku (kornastærð, lögun agna í öskunni og hve hvassar brúnir peirra eru). Bráð áhrif felast aðallega í auknum astmaeinkennum, einkum hjá börnum. Ný aska er oft hlaðin virkum skaðlegum efnum og er með hvassar brúnir, sem ertir loftvegi, en „eldri“ aska sem hefur veðrast er eðlislík annarri svifryksmengun vegna fjúkandi jarðvegs og borgarryks. Раð fer eftir pví hve mikið og oft öskufok liggur yfir byggð, hvort vel pekktar afleiðingar svifryksmengunar með skertum lungnaproska barna ${ }^{4}$ og hraðara tapi á öndunargetu fullorðinna ${ }^{5}$ koma fram eða ekki.

Rannsóknir sem birst hafa allra síðustu ár benda til pess að einkenni frá öndunarfærum samhliða eldgosum séu mest (og einkum hjá börnum) ef gosinu fylgir mikil mengun brennisteins. ${ }^{6}$ Í kjölfar eldgossins í Ruapehufjalli á Nýja-Sjálandi 1996 kom fram marktækt hækkuð dánartíðni vegna öndunarfærasjúkdóma í Auckland sem er í 280 km fjarlægð frá eldfjallinu, en hjá viðmiðunarhópi sem bjó enn fjær.7 Með eldgosum getur fylgt mengun margskonar málma og annarra frumefna. Vakin hefur verið athygli á hugsanlegum tengslum krabbameins (skjaldkirtill) og eldvirkni. ${ }^{8}$ Samanburðarrannsóknir benda til meira magns pungmálma meðal bæði manna og dýra á gosvirkum hluta Asóreyja en á öðrum svæðum eyjanna.
Mælingar pær sem ég pekki til á gosösku, málmum og lofttegundum frá Eyjafjallajökli gefa ekki tilefni til pess að halda að við stöndum frammi fyrir bráori heilsufarsvá. Vart hefur orðið við versnun astmaeinkenna og fjölmargir hafa fundið fyrir ertingi í augum, nefi, koki og lungum. Einkenni hafa verið skammvinn, svarað meðferð vel og horfið fljótt pegar mengun var ekki lengur til staðar. Pegar petta er ritað um miðjan júní 2010 höfum við ekki orðið vör við auknar innlagnir á Landspítala í tengslum við gosið. Að frumkvæði sóttvarnarlæknis, Haraldar Briem, hafa á undanförnum tveimur vikum á priðja hundrað íbúar undir Eyjafjöllum verið skoðaðir á kerfisbundinn hátt, meðal annars með blástursprófi sem endurtekið var eftir gjöf berkjuvíkkandi lyfs. Niðurstaðna peirra prófa er brátt að vænta.

Fjölmörgum spurningum um hugsanleg heilsufarsáhrif er pó ósvarað, ekki síst um langtímaáhrif. Pær takmörkuðu upplýsingar sem til eru um heilsufarslegar afleiðingar eldgosa annars staðar 1 heiminum eiga aðeins að hluta við hér á landi. Раð er mikilvægt аð við hefjumst strax handa við að afla nauðsynlegra gagna svo unnt verði að draga ályktanir um heilsufarsleg áhrif eldgossins í Eyjafjallajökli. Nauðsynlegt er að koma á víðtækri samvinnu meðal annars lækna, dýralækna, sálfræðinga, líffræðinga, jarðvísindamanna og veðurfræðinga. Brýnt er að sú metnaðarfulla skráning heilsufarsupplýsinga sem fer fram á Íslandi komi að notum við pessar rannsóknir. pær geta orðið mikilvægt framlag til pekkingar á áhrifum eldgosa á heilsufar og vísað okkur veginn varðandi viðbrögð og ráðleggingar til íbúa hamfarasvæða.

\section{Heimildir}

1. Hansell A, Oppenheimer C. Health hazards from volcanic gases: a systematic literature review. Arch Environ Health 2004; 59: 628-39.

2. Hansell AL, Horwell CJ, Oppenheimer C. The health hazards of volcanoes and geothermal areas. Occup Environ Med 2006; 63: 149-56.

3. Horwell C, Baxter P. The respiratory health hazards of volcanic ash: a review for volcanic risk mitigation. Bull Volc 2006; 69: 1-24.

4. Gauderman WI, Vora H, McConnell R, et al. Effect of exposure to traffic on lung development from 10 to 18 years of age: a cohort study. Lancet 2007; 369: 571-7.

5. Downs SH, Schindler C, Liu LJ, et al. Reduced exposure to PM10 and attenuated age-related decline in lung function. N Engl J Med 2007; 357: 2338-47.

6. Iwasawa S, Kikuchi Y, Nishiwaki Y, et al. Effects of SO2 on respiratory system of adult Miyakejima resident 2 years after returning to the island. J Occup Health 2009; 51: 38-47.

6. Newnham RM, Dirks KN, Samaranayake D. An investigation into long-distance health impacts of the 1996 eruption of Mt Ruapehu, New Zealand. Atmosph Environ 201; 44: 1568-78.

7. Duntas LH, Doumas C. The ,rings of fire' and thyroid cancer. Hormones 2009; 8: 249-53. 